\title{
Disparity in public funding of therapies for metastatic castrate-resistant prostate cancer across Canadian provinces
}

Dixon T.S. Woon ${ }^{1}$; Thenappan Chandrasekar ${ }^{1}$; Lorne Aaron ${ }^{2}$; Naveen S. Basappa ${ }^{3}$; Kim N. Chi ${ }^{4}$; Henry J. Conter ${ }^{5}$; Geoffrey Gotto ${ }^{3}$; Sebastien J. Hotte ${ }^{6}$; Shawn Malone ${ }^{7}$; Fred Saad ${ }^{8}$; Bobby Shayegan $^{6}$; Laura Park-Wyllie ${ }^{9}$; Robert J. Hamilton ${ }^{1}$

${ }^{1}$ Princess Margaret Cancer Centre, University of Toronto, Toronto, ON; ${ }^{2}$ Service d-Urologie and Centre de la Prostate, Hôpital Charles LeMoyne, Longueuil, QC; ${ }^{3}$ Southern Alberta Institute of Urology, University of Calgary, Calgary AB; ${ }^{4} \mathrm{BC}$ Cancer Agency, University of British Columbia, Vancouver, BC; ${ }^{5}$ William Osler Health System, University of Western Ontario, Brampton, ON; ${ }^{6}$ Juravinski Cancer Centre, McMaster University, Hamilton, ON; ${ }^{7}$ The Ottawa Hospital, University of Ottawa, Ottawa, ON; ${ }^{8}$ Centre Hospitalier de l’Université de Montréal, University of Montreal, Montreal, QC; ${ }^{9}$ Medical Affairs, Janssen Inc., Toronto, ON; Canada

Funding: Disparity analysis was funded by Janssen Inc.

Cite as: Can Urol Assoc J 2018 July 16; Epub ahead of print. http://dx.doi.org/10.5489/cuaj.5378

Published online July 16, 2018

$* * *$

Abstract

Introduction: Treatment using abiraterone acetate plus prednisone, enzalutamide, cabazitaxel, and radium-223 (Ra-223) improve overall survival (OS) and quality of life for patients with metastatic castrate-resistant prostate cancer (mCRPC). Despite their proven benefits, access to these therapies is not equal across Canada.

Methods: We describe provincial differences in access to approved mCRPC therapies. Data sources include the pan-Canadian Oncology Drug Review database, provincial cancer care resources, and correspondence with pharmaceutical companies.

Results: Both androgen receptor-axis-targeted therapies (ARATs) abiraterone acetate plus prednisone, and enzalutamide are funded by provinces in the pre-and post-chemotherapy setting, however, sequential ARAT use is not funded. "Sandwich" therapy, where one ARAT is used prechemotherapy and a second is used upon progression on chemotherapy is funded in six provinces: Ontario (ON), Alberta, New Brunswick, Prince Edward Island (PEI), Nova Scotia (NS) and Newfoundland \& Labrador. Ra-223 is funded in five provinces: ON, Quebec (QC), British Columbia (BC), Saskatchewan, and Manitoba to varying degrees; ON allows Ra-223 either preor post-chemo (not both); QC allows Ra-223 post-chemo unless chemo is not tolerated; BC allows Ra-223 if other life-prolonging mCRPC therapies have been received or ineligible. Cabazitaxel is funded in all provinces post-docetaxel, except QC and PEI. Cabazitaxel is not funded as fist-line treatment for mCPRC or in combination with other agents. In ON, BC, QC, and PEI, cabazitaxel is not funded after progression on an ARAT in the post-chemotherapy setting.

Conclusions: While all provinces have access to docetaxel and ARATs, sandwiching sequential ARATs with docetaxel is funded only in select provinces. Ra-223 and cabazitaxel access is not 
ubiquitous across Canada. Such inequalities in access to life-prolonging therapies could lead to disparities in survival and quality of life among patients with mCRPC. Further research should quantify inter-provincial variation in outcomes and cost that may result from variable access.

\section{Introduction}

For men whose prostate cancer recurs after local therapy or who present with metastatic disease, no curative options exist. The standard treatment is androgen deprivation therapy (ADT), either in the form of surgical or medical castration. ADT is effective in relieving symptoms and has been demonstrated to delay disease progression, but eventually all patients will progress to castrationresistant prostate cancer (CRPC). Progression may present as a rise in prostate specific antigen (PSA) levels despite castrate levels of testosterone ( $<50 \mathrm{ng} / \mathrm{dl}, 1.73 \mathrm{mmol} / \mathrm{L}$ ), symptomatic progression or the radiographic appearance of new metastases.

Prior to 2010, docetaxel-based chemotherapy was the only agent with proven ability to prolong overall survival (OS) in patients with metastatic CRPC (mCRPC); median OS was improved by 2.4 months with docetaxel and prednisone compared to mitoxantrone and prednisone. [1]

Since 2010, there has been exponential growth in treatments available for mCRPC. There are now four Health Canada approved therapies, all of which have shown improvements in OS (Table 1). Abiraterone acetate plus prednisone and enzalutamide are new androgen receptor axistargeted (ARAT) agents. Cabazitaxel is a microtubule stabilizing chemotherapeutic agent and radium-223 is a radio-pharmaceutical that improves OS and reduces symptomatic skeletal events (SSEs).

Contemporary management of mCRPC is complex and is constantly evolving. A summary of the current Canadian Urological Association Canadian Urologic Oncology Group (CUA-CUOG) guideline supporting the use of the agents discussed in this study is shown in Figure 1[6]. Unfortunately, access to these mCPRC agents globally is variable.

Even within Canada's publicly funded health system, there is interprovincial variation in access to treatments for mCRPC. Because of the importance of inequity in access to lifeprolonging treatments within a national health system, the Canadian Genitourinary Research Consortium (GURC), a collaborative network of community and academic uro-, medical, and radiation oncologists prioritized this issue as an important barrier to best practice and set out to undertake a descriptive analysis of interprovincial funding policies for mCRPC treatments. The GURC also conducted a survey of uro-, radiation, and medical oncologists specialized in the care of patients with advanced prostate cancer to understand real world preferences and barriers encountered in access to mCRPC treatments.

In this paper, we describe the specific nuances of mCRPC therapy availability in each province to characterize the interprovincial disparities in access, explore barriers and potential consequences this disparity may introduce and contrast the access with treatment preferences and perceived barriers as reported in the Canadian GURC survey [7]. 


\section{Methods}

\section{Information sources}

To characterize the nuances of access to mCRPC therapies across Canada we interrogated the Canadian Agency for Drugs and Technologies in Health (CADTH) pan-Canadian Oncology Drug Review (pCODR) provincial funding summaries[8]. pCODR is an evidence-based cancer drug review program that conducts thorough and objective evaluations of clinical, economic and patient-based evidence on Health Canada approved cancer drugs to provide reimbursement recommendations to provincial public drug plans and cancer agencies. The drug plans and cancer agencies make their final reimbursement and coverage decisions based on the CADTH recommendations and other factors, such as their program mandates, jurisdictional priorities and budget impact. Provincial funding decisions and criteria are summarized as 'Provincial Funding Summaries' on the pCODR website after posting their reimbursement recommendations[8].

Quebec does not participate in the pCODR process and thus information came solely from provincial formulary sources and pharmaceutical companies. Yukon, Northwest Territories and Nunavut were excluded from this study due to their small population size and because limited information could be obtained from available sources. As radium-223 has not been reviewed by the pCODR, funding status in each of the provinces was obtained directly from the company (Bayer Inc.).

Supplemental information sources included: provincial cancer care guidelines and formularies; pharmaceutical manufacturers who are market authorization holders for the treatments in Canada; and the GURC network of clinicians who treat mCRPC in their provinces.

\section{Descriptive analysis of interprovincial disparity}

Funding decisions and reimbursement criteria are described by province and we have characterized the nuances of access to mCRPC therapies across Canada, highlighting where disparities and commonalities exist.

To summarize pictographically the interprovincial variation in access we developed a heat map that reflects the key differentiating factors related to access across the provinces as a composite score or shade.

In order to examine current treatment access to drugs against real-world patterns of treatment and issues with treatment access, we also examined preferred treatment practice patterns and barriers to treatment access as reported from the GURC Canadian survey of uro-, radiation, and medical oncologists specialized in the care of patients with advanced prostate cancer [9].

\section{Results}

\section{Androgen receptor axis-targeted therapy (ARAT)}

Both abiraterone acetate plus prednisone and enzalutamide are currently funded by all provinces in pre- and post-chemotherapy mCRPC patients with minor variations in criteria between abiraterone acetate plus prednisone and enzalutamide. However, disparities across provinces exist in access to ARAT therapy for use both pre-docetaxel and post-docetaxel ('sandwich therapy', see below) and no provinces allow use of sequential ARAT therapy unless intolerance is encountered. 


\section{Enzalutamide}

In general, in patients with chemo-naïve mCRPC, enzalutamide is funded across Canada for asymptomatic or mildly symptomatic patients with no risk factors for seizures. However, minor variation in the criteria do exist between the provinces (Table 2). For example, in Manitoba, prescribers need to be affiliated with a cancer centre; in Alberta, only approved designated physicians can prescribe enzalutamide; and in BC, patients must have $\geq 3$ months life expectancy.

In the post-docetaxel setting, for patients who have not yet received an ARAT, enzalutamide is reimbursed across Canada. For patients who received enzalutamide prior to docetaxel, enzalutamide is not funded in the post-docetaxel setting. In Newfoundland and Labrador, approval must be renewed every 4 months with no evidence of disease progression or unacceptable toxicities.

\section{Abiraterone acetate plus prednisone}

Abiraterone acetate plus prednisone is funded across Canada for patients with asymptomatic or mildly symptomatic mCRPC in both pre- and post-docetaxel settings (Table 3). Ontario and BC have specific criteria regarding hepatic, cardiac or renal function for eligibility. In Ontario, funding is ceased upon disease progression. Similar restriction probably exists in other provinces, but is not documented in the pCODR's provincial funding summary.

In Manitoba, prescribers need to be affiliated with a cancer centre. In Alberta and PEI, only approved designated physicians can prescribe. For example, in PEI, coverage must be requested by a specialist in haematology or medical oncology or a general practitioner acting under the direction of those specialists.

In the post-docetaxel setting, for patients who have never received an ARAT, abiraterone acetate plus prednisone is reimbursed across Canada. For patients who had abiraterone acetate plus prednisone before, abiraterone acetate plus prednisone is not funded in the post-docetaxel setting.

\section{Sequential and/or "sandwich" ARAT use}

While provinces generally use similar criteria for use of abiraterone acetate plus prednisone and enzalutamide, there are differences across provinces in funding of ARAT for sequential or 'sandwich' use. Across Canada, only one ARAT agent is funded in the pre-docetaxel setting. If progression on one agent is documented, no province will fund another ARAT to be used sequentially (ARAT followed by ARAT). In Ontario, if patients discontinue the first-line ARAT because of intolerable adverse effects within 3 months, and there is no documented disease progression, switching to a second ARAT is considered on a case-by-case basis in the predocetaxel setting.

If an ARAT was not utilized in the pre-docetaxel setting, it is funded for post-docetaxel use. However, similar principles apply in that sequential ARAT use is not funded, with the exception of Ontario where a switch can be made because of adverse effects.

Importantly some provincial agencies fund the use of a second ARAT after a prior ARAT provided chemotherapy was used in between (eg. Abiraterone acetate plus prednisone - docetaxel 
- enzalutamide). This so called "sandwich therapy", is allowed in Ontario, Alberta, New Brunswick, Prince Edward Island, Nova Scotia, New Foundland, and Labrador (one half of Canadian provinces), and is indicated Table 2 and Table 3.

\section{Radium-223}

Radium-223 was not reviewed by pCODR, leaving each province to review it independently. It is currently funded in Ontario, Quebec, British Columbia, Saskatchewan, and Manitoba, (Table 5), leaving approximately $20 \%$ of the Canadians without coverage. In general, funding covers symptomatic bone metastases with no visceral metastatic disease. In Ontario, combination with other novel agents (enzalutamide, abiraterone acetate plus prednisone, or cabazitaxel) is not funded; and if radium-223 is funded in the pre-docetaxel setting, no further funding is available in the post-docetaxel setting. The other four provinces probably have similar restrictions, but is not explicitly stated.

\section{Chemotherapy: Docetaxel and cabazitaxel}

Docetaxel is funded across Canada without restriction. Cabazitaxel, used after docetaxel, is currently funded by all provincial drug programs except Quebec and PEI (Table 4). No ECOG or clinical status requirements are stated. However, cabazitaxel is not funded if it is used in combination with other novel agents or as first line for mCRPC. In Ontario, BC, QC, and PEI, cabazitaxel is also not funded if a patient has received abiraterone acetate plus prednisone, enzalutamide or radium-223 in the post-docetaxel setting, but if a patient fails on abiraterone acetate plus prednisone or enzalutamide, switching to cabazitaxel is often allowed within three months of starting the ARATs.

\section{Heat map of interprovincial access}

Figure 2 represents our consensus summary of each province's access to mCRPC therapies, with dark blue representing greater access and light blue representing less access.

\section{Preferred lines of therapy vs interprovincial access}

Based on a recent Canadian survey conducted by the GURC, ARAT was reported as the preferred first line for mCRPC, followed by docetaxel as second line and an ARAT or radium-223 as the third line (Figure 3). Cabazitaxel was the therapy used most as fourth line therapy along with radium-223. [9].

However, real-world preferences reported by the survey respondents showed a disconnect between preferred access and actual access to mCRPC treatment. Nearly 2/3 of physicians (65\%) cited limitations related to ARAT access, followed by $59 \%$ for cabazitaxel, and $45 \%$ for radium223. 


\section{Discussion}

The landscape of prostate cancer care has changed dramatically in the last 8 years. With 4 new agents, each proven to prolong survival, treatment options for patients entering mCRPC are now plentiful and provide options to use therapies in sequence. However, access to these new agents globally is variable and as we observed in our study, disparities exist across provinces in Canada.

Docetaxel is funded in all provinces without restriction. Abiraterone acetate plus prednisone and enzalutamide are funded by all provinces in the pre-and post-chemotherapy settings, however sequential use is not funded in any province, and the use of one ARAT prechemotherapy and the other ARAT post-chemotherapy (sandwich therapy) is not funded in BC, Saskatchewan, Manitoba, and Quebec. Cabazitaxel use after docetaxel is funded in all provinces except Quebec and PEI. The greatest disparity was noted for government-funded access to radium-223 where funding was available in only 5 provinces. In our survey of provincial funded therapies, the most desired therapy sequence was an ARAT followed by docetaxel, followed by another ARAT. However, such sandwich therapy is only funded in 6 provinces.

Combined, there are clearly provinces that fund more treatment options and there are provinces with relatively limited treatment access. Such inequalities in access to life-prolonging therapies could lead to differences in survival and quality of life among patients with mCRPC and calls into question if such inequalities should persist in a country with universal health care.

Although one of the goals of the Canada Health Act, adopted in 1984, was to equalize the level of care across the provinces, it did not specify how health care should be organized and/or delivered; this is left to the jurisdiction of the provinces and this includes decisions pertaining to medication coverage[10]. For a new therapy to be approved for sale in Canada, a pharmaceutical company must first apply to Health Canada, which then reviews published data on the agent's safety and clinical effectiveness. Following approval by Health Canada, pCODR evaluates the scientific evidence and the associated cost to decide if the new cancer therapy is clinically efficacious and cost-effective [8]. pCODR will then provide public funding recommendations to the provinces, with the exception of Quebec, where this process is conducted by the Institute National d'Excellence en Santé et en Services Sociaux[11]. pCODR recommendations are not binding[12]. Each provincial Ministry of Health and cancer agency makes independent decisions on treatment funding. Therefore, a delay or rejection of funding by individual provinces can create a serious impediment or even lack of access to new treatments for provincial residents. Disparity is well documented in other cancer drug funding. The use of adjuvant hormonal therapy to lower breast cancer recurrence risk [13], and use of monoclonal antibodies in metastatic colorectal cancer[14] are some examples. In provinces where these new therapies are not funded publicly, patients may still be able to access it through private health insurance, out-of-pocket pay or through compassionate drug release programs.

The new agents for mCRPC certainly improve outcomes for patients, but they are expensive and this is likely the most influential reason why all provinces have not agreed to fund all therapies. For example, based on the information from pharmaceutical companies, the cost per 28-day cycle for docetaxel, abiraterone acetate plus prednisone, enzalutamide, radium-223, and cabazitaxel are \$1217, \$3551, \$3270, \$5640 and \$7738 respectively. 
Disparity in public access to Radium-223 is interesting, as we observed the greatest disparity here; only 5 provinces offer any coverage. Current estimates suggest $20 \%$ of Canadian men cannot receive this treatment due to lack of funding. This may be, in part, because radium223 was the last of the new agents to seek Health Canada approval. It may also be because, as a radiopharmaceutical, radium-223 did not go through the usual pCODR process. Yet, it is currently the only bone-targeting agent with proven OS benefit[15]. Furthermore, it reduces the risk of serious skeletal events (SSEs) that are known to cause significant morbidity, mortality and cost [16-18]. A Canadian study suggested the annual cost of patients with metastatic bone disease was $\$ 11,820$ CAD more than those without and these costs were mostly attributable to resource utilization secondary to SSEs. Thus, it could be argued that patients in the provinces without access to radium-223 are placed at a notable health disadvantage, and there may be a role for Canadian-based cost-effectiveness studies to determine if funding radium -223 could potentially be cost-neutral or cost-saving.

Our findings suggest a problem of inequality across Canada. Advanced prostate cancer is but one model to study this problem, however it is a particularly sensitive model as the landscape is changing rapidly. More drugs with proven survival benefit are forthcoming. The drugs are being tested in earlier disease stages, and translating into life prolongation, meaning patients will be on the drugs for significantly longer periods.

Our study has some limitations. The accuracy of information for certain drugs in certain provinces (e.g. radium-223 in Manitoba) is not entirely clear as the provinces may not have released all approval details. To combat this, we requested additional information from pharmaceutical companies and have spoken to providers in those provinces to validate information. Information on drug coverage was not available for the territories, however, this represents $<0.01 \%$ of the Canadian population. Finally, our study merely captured drug funding. What remains unknown is the actual interprovincial utilization and whether access also translates into improvements in survival and quality of life between provinces.

\section{Conclusion}

Provincial access to approved mCRPC therapies varies across Canada. While access to docetaxel and ARATs was mostly ubiquitous, there were funding differences that hinder the ability to optimally sequence these agents how providers would ideally like. Cabazitaxel after docetaxel is not approved in Quebec or PEI. However, the greatest disparity was observed with radium-223 where 5 provinces, comprising approximately $20 \%$ of the Canadian population, currently do not have access.

While men with mCRPC are living longer, the cost of treating advanced prostate care is rising, which could lead to a widening of interprovincial inequality. Further studies are needed to explore the cost-effectiveness of these drugs in a Canadian setting and whether survival and quality of life is significantly superior in the provinces with high access, as compared to those with limited access. 


\section{References}

1. Tannock, I.F., et al., Docetaxel plus prednisone or mitoxantrone plus prednisone for advanced prostate cancer. The New England journal of medicine, 2004. 351(15): p. 150212.

2. Beer, T.M., et al., Enzalutamide in Men with Chemotherapy-naive Metastatic Castrationresistant Prostate Cancer: Extended Analysis of the Phase 3 PREVAIL Study. Eur Urol, 2017. 71(2): p. 151-154.

3. Ryan, C.J., et al., Abiraterone in metastatic prostate cancer without previous chemotherapy. N Engl J Med, 2013. 368(2): p. 138-48.

4. Petrylak, D.P., et al., Docetaxel and estramustine compared with mitoxantrone and prednisone for advanced refractory prostate cancer. The New England journal of medicine, 2004. 351(15): p. 1513-20.

5. Ryan, C.J., et al., Abiraterone acetate plus prednisone versus placebo plus prednisone in chemotherapy-naive men with metastatic castration-resistant prostate cancer (COU-AA302): final overall survival analysis of a randomised, double-blind, placebo-controlled phase 3 study. Lancet Oncol, 2015. 16(2): p. 152-60.

6. Saad, F., et al., The 2015 CUA-CUOG Guidelines for the management of castrationresistant prostate cancer (CRPC). Can Urol Assoc J, 2015. 9(3-4): p. 90-6.

7. Hotte, J.H., Finelli, A., Malone, S, Shayegan, B. So, A, Canil, C.M., Hew, H., ParkWyllie, L., Saad, F., Chi, K., Real world patterns of treatment sequencing in Canada for metastatic castrate-resistant prostate cancer. J Clin Oncol 2018. 36: p. suppl 6S; abstr 320.

8. pan-Canada Oncology Drug Review (pCORD) provincial funding summaries. . https://cadth.ca/pcodr.

9. Shayegan, B., So, A., Malone, S., Hotte, S. et al. , Patterns of prostate cancer management across Canadian prostate cancer treatment specialists. J Clin Oncol 2018. 36(suppl 6S; abstr 321).

10. Canada Health Act. RSC. 1985.

11. Institut national d'excellence en santé et en services sociaux. http://www.inahta.org/members/inesss/.

12. Vogel, L., Pan-Canadian review of cancer drugs will not be binding on provinces. CMAJ, 2010. 182(9): p. 887-8.

13. Verma, S., S. Sehdev, and A.A. Joy, Cancer therapy disparity: unequal access to breast cancer therapeutics and drug funding in Canada. Curr Oncol, 2007. 14 Suppl 1: p. S3-10.

14. Berry, S.R., et al., Variation and consternation: access to unfunded cancer drugs in Canada. J Oncol Pract, 2012. 8(1): p. 35-9.

15. Parker, C., et al., Alpha emitter radium-223 and survival in metastatic prostate cancer. $\mathrm{N}$ Engl J Med, 2013. 369(3): p. 213-23.

16. DePuy, V., et al., Effects of skeletal morbidities on longitudinal patient-reported outcomes and survival in patients with metastatic prostate cancer. Support Care Cancer, 2007. 15(7): p. 869-76. 
17. Inoue, T., et al., Prevalence of skeletal complications and their impact on survival of hormone refractory prostate cancer patients in Japan. Urology, 2009. 73(5): p. 1104-9.

18. Weinfurt, K.P., et al., The significance of skeletal-related events for the health-related quality of life of patients with metastatic prostate cancer. Ann Oncol, 2005. 16(4): p. 57984.

19. Saad, F., Chi, K., Finelli, A., The 2015 CUA-CUOG Guidelines for the management of castration-resistant prostate cancer (CRPC). Can Urol Assoc J, 2015. 9(3-4): p. 90-96.

20. Scher, H.I., et al., Increased survival with enzalutamide in prostate cancer after chemotherapy. N Engl J Med, 2012. 367(13): p. 1187-97.

21. de Bono, J., C. Logothetis, and A. Molina, et al, Abiraterone and Increased Survival in Metastatic Prostate Cancer. N Engl J Med, 2011. 364: p. 1995-2005.

22. de Bono, J.S., et al., Prednisone plus cabazitaxel or mitoxantrone for metastatic castration-resistant prostate cancer progressing after docetaxel treatment: a randomised open-label trial. Lancet, 2010. 376(9747): p. 1147-54. 


\section{Figures and Tables}

Fig. 1. CUA-CUOG 2015 guideline on the management of mCRPC.[19]
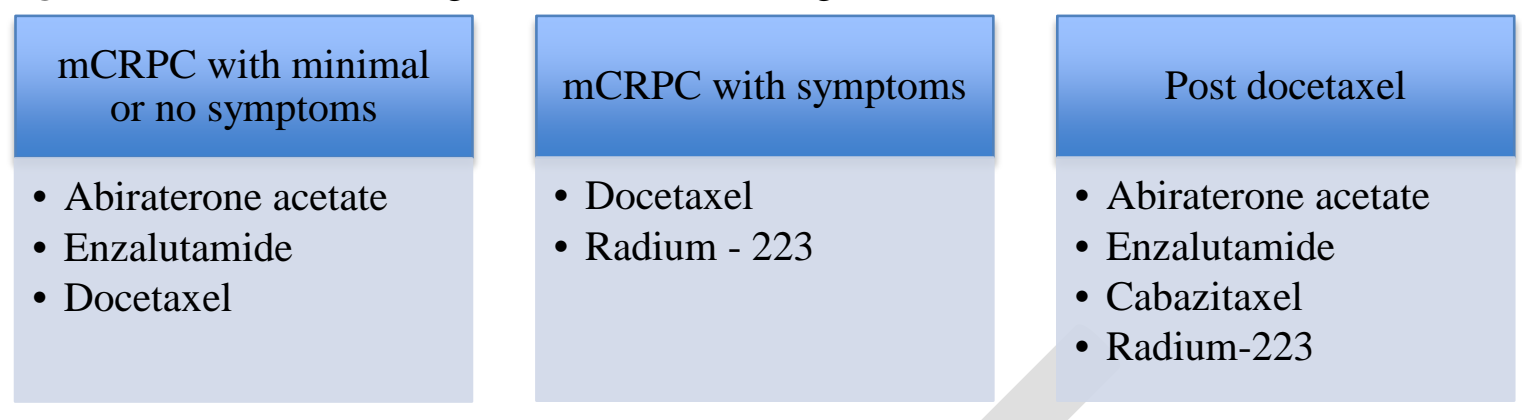

Fig. 2. Pictographic description of variation in interprovincial access to life-prolonging therapies in mCRPC.

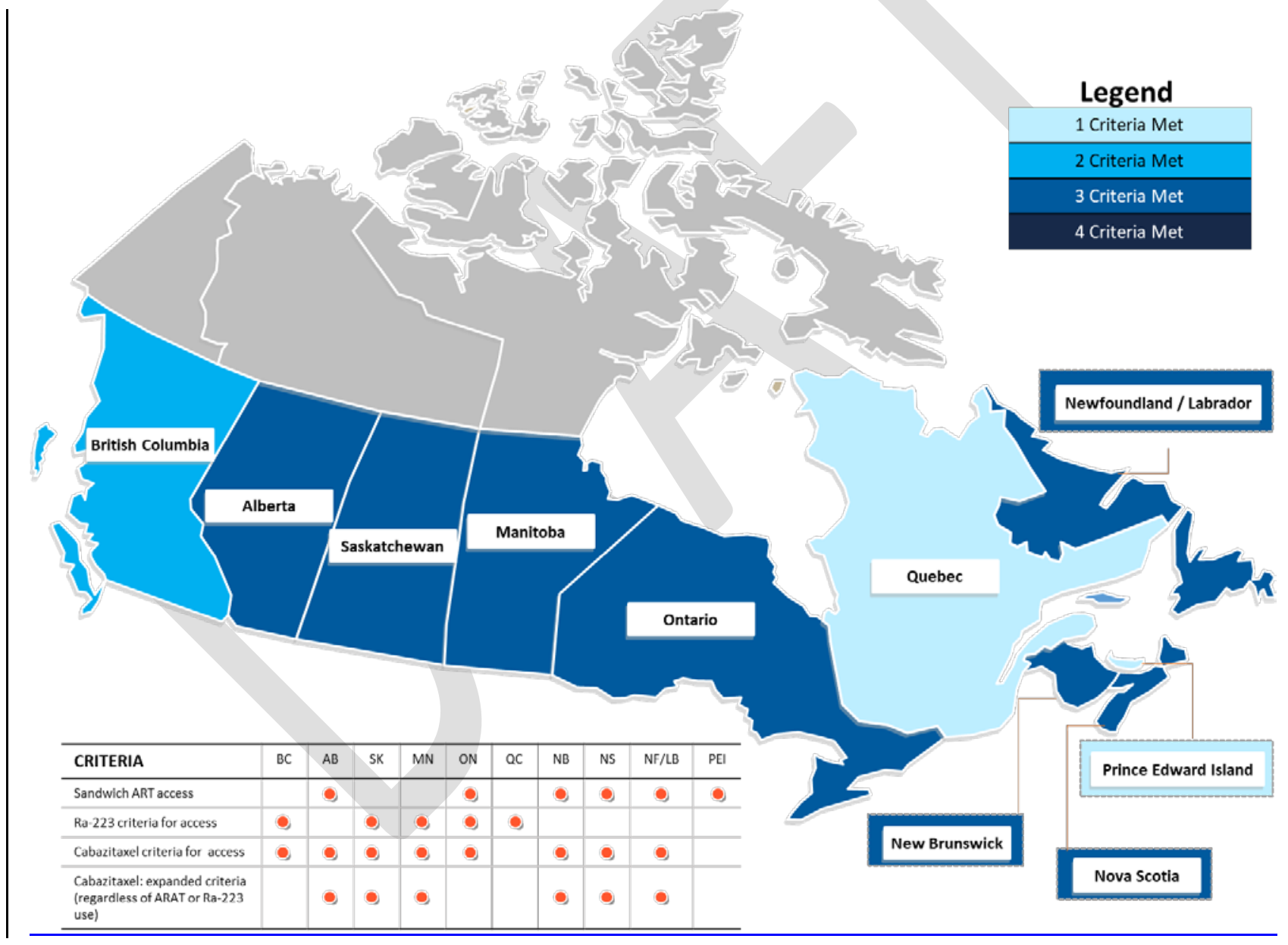


Fig. 3. Real-world line 1 to line 3 treatment sequencing in mCRPC

\begin{tabular}{|c|c|c|c|}
\hline $33 \%$ of physicians & AR-targeted therapy & Docetaxel & AR-targeted therapy \\
\hline $14 \%$ of physicians & AR-targeted therapy & Docetaxel & Radium-223 \\
\hline $6 \%$ of physicians & AR-targeted therapy & Docetaxel & Cabazitaxel \\
\hline $4 \%$ of physicians & AR-targeted therapy & Radium-223 & Docetaxel \\
\hline $4 \%$ of physicians & AR-targeted therapy & Radium-223 & Docetaxel or Radium -223 \\
\hline $4 \%$ of physicians & AR-targeted therapy & -targeted therapy & Docetaxel \\
\hline $4 \%$ of physicians & AR-targeted therapy & Docetaxel & Docetaxel \\
\hline
\end{tabular}

*The remaining lines of treatment sequencing are not shown due to small numbers. 


\begin{tabular}{|c|c|c|}
\hline Treatment & Overall survival (OS) benefit & $\begin{array}{l}\text { Common side effects } \\
\text { (Grade 3-4) }\end{array}$ \\
\hline $\begin{array}{l}\left.\text { Enzalutamide (Xtandi }{ }^{(}\right) \\
\text {Astellas) } \\
\text { Pre-docetaxel } \\
\text { Post-docetaxel }\end{array}$ & $\begin{array}{l}4.0 \text { months compared with placebo[2] } \\
4.8 \text { months compared with placebo[20] }\end{array}$ & $\begin{array}{l}\text { Fatigue, back pain, } \\
\text { arthralgia, and } \\
\text { hypertension[2] }\end{array}$ \\
\hline $\begin{array}{l}\text { Abiraterone acetate plus } \\
\text { prednisone (Zytiga }^{\circledR}, \\
\text { Janssen) } \\
\text { Pre-docetaxel } \\
\text { Post-docetaxel }\end{array}$ & $\begin{array}{l}4.4 \text { months compared with placebo [5] } \\
4.6 \text { months compared with placebo[21] }\end{array}$ & $\begin{array}{l}\text { Anaemia, liver function test } \\
\text { abnormalities, hypokalemia, } \\
\text { and fluid retention [5] }\end{array}$ \\
\hline $\begin{array}{l}\text { Docetaxel (Taxotere }{ }^{\circledR} \text {, } \\
\text { Sanofi) }\end{array}$ & $\begin{array}{l}\text { 2.4-3.0 months compared with } \\
\text { mitoxantrone }[1,4]\end{array}$ & $\begin{array}{l}\text { Neutropenia, anaemia, } \\
\text { thrombocytopenia, and } \\
\text { fatigue }\end{array}$ \\
\hline $\begin{array}{l}\text { Cabazitaxel (Jevtana }{ }^{(B)} \text {, } \\
\text { Sanofi) }\end{array}$ & 2.4 months compared with mitoxantrone [22] & $\begin{array}{l}\text { Neutropenia, anaemia, } \\
\text { thrombocytopenia, and } \\
\text { fatigue }\end{array}$ \\
\hline $\begin{array}{l}\text { Radium-223 } \text { (Xofigo }^{(}, \\
\text {Bayer) }\end{array}$ & 3.6 months compared with placebo [15] & $\begin{array}{c}\text { Anaemia, neutropenia } \\
\text { thrombocytopenia, and bone } \\
\text { pain }\end{array}$ \\
\hline
\end{tabular}




\begin{tabular}{|c|c|c|c|c|c|c|}
\hline Province & Enzalutamide & Symptomatic & $\begin{array}{l}\text { ECOG } \\
\text { status }\end{array}$ & $\begin{array}{c}\text { Is } \\
\text { "sandwich" } \\
\text { therapy } \\
\text { allowed? }\end{array}$ & Exclusion criteria & Other criteria \\
\hline \multirow[t]{2}{*}{ Ontario } & Pre-docetaxel & $\begin{array}{l}\text { Asymptomatic } \\
\text { or mildly } \\
\text { symptomatic }\end{array}$ & $0-1$ & & $\begin{array}{l}\text { Risk factors for } \\
\text { seizures } \\
\text { Disease progression } \\
\text { on enzalutamide }\end{array}$ & $\begin{array}{c}\text { Switching from } \\
\text { abiraterone acetate plus } \\
\text { prednisone to } \\
\text { enzalutamide in patients } \\
\text { who have not progressed } \\
\text { on abiraterone acetate plus } \\
\text { prednisone is considered } \\
\text { on a case by case basis }\end{array}$ \\
\hline & Post-docetaxel & & $0-2$ & & $\begin{array}{l}\text { Risk factors for } \\
\text { seizures }\end{array}$ & $\begin{array}{c}\text { May approve } \\
\text { enzalutamide use after } \\
\text { cabazitaxel or abiraterone } \\
\text { acetate plus prednisone } \\
\text { provided no progression } \\
\text { has occurred in } 3 \text { months. }\end{array}$ \\
\hline \multirow[t]{2}{*}{ Quebec } & Pre-docetaxel & $\begin{array}{l}\text { Asymptomatic } \\
\text { or mildly } \\
\text { symptomatic }\end{array}$ & $0-1$ & No & $\begin{array}{l}\text { Prior enzalutamide } \\
\text { or abiraterone } \\
\text { acetate plus }\end{array}$ & \\
\hline & Post-docetaxel & & $0-2$ & No & $\begin{array}{l}\text { Prior enzalutamide } \\
\text { or abiraterone } \\
\text { acetate plus } \\
\text { prednisone } \\
\text { treatment } \\
\end{array}$ & \\
\hline \multirow[t]{2}{*}{ Alberta } & Chemo-naive & $\begin{array}{l}\text { Asymptomatic } \\
\text { or mildly } \\
\text { symptomatic }\end{array}$ & & 5 & & $\begin{array}{c}\text { Enzalutamide is } \\
\text { prescribed by approved } \\
\text { designated prescribers } \\
\text { only. }\end{array}$ \\
\hline & Post-docetaxel & & 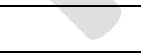 & Yes & Prior enzalutamide & \\
\hline \multirow[t]{2}{*}{$\begin{array}{l}\text { British } \\
\text { Columbia }\end{array}$} & Pre-docetaxel & & $0-2$ & & & $\begin{array}{c}\text { Life expectancy }>3 \\
\text { months }\end{array}$ \\
\hline & Post-docetaxel & & & No & Prior enzalutamide & $\begin{array}{l}\text { Only one ARAT is } \\
\text { funded. ** }\end{array}$ \\
\hline \multirow[t]{2}{*}{$\begin{array}{l}\text { Saskatche } \\
\text { wan }\end{array}$} & Pre-docetaxel & $\begin{array}{l}\text { Asymptomatic } \\
\text { or mildly } \\
\text { symptomatic }\end{array}$ & & & & \\
\hline & Post-docetaxel & Symptomatic & $0-1$ & No & & \\
\hline Manitoba & Pre-docetaxel & & & & & $\begin{array}{l}\text { Prescribers need to be } \\
\text { affiliated with a cancer } \\
\text { centre } \\
\text { Histologically confirmed } \\
\text { mCRPC with disease } \\
\text { progression }\end{array}$ \\
\hline
\end{tabular}




\begin{tabular}{|c|c|c|c|c|c|c|}
\hline & Post-docetaxel & & $0-2$ & No & $\begin{array}{l}\text { Risk factors for } \\
\text { seizures }\end{array}$ & $\begin{array}{l}\text { prescribers need to be } \\
\text { affiliated with a cancer } \\
\text { centre }\end{array}$ \\
\hline \multirow[t]{2}{*}{$\begin{array}{l}\text { Nova } \\
\text { Scotia }\end{array}$} & Pre-docetaxel & $\begin{array}{l}\text { Asymptomatic } \\
\text { or mildly } \\
\text { symptomatic }\end{array}$ & $0-1$ & & $\begin{array}{l}\text { Risk factors for } \\
\text { seizure }\end{array}$ & \\
\hline & Post-docetaxel & & $0-2$ & Yes & $\begin{array}{l}\text { Risk factors for } \\
\text { seizure }\end{array}$ & \\
\hline \multirow[t]{2}{*}{$\begin{array}{l}\text { New } \\
\text { Brunswick }\end{array}$} & Pre-docetaxel & $\begin{array}{l}\text { Asymptomatic } \\
\text { or mildly } \\
\text { symptomatic }\end{array}$ & 0 & & $\begin{array}{l}\text { Risk factors for } \\
\text { seizure }\end{array}$ & \\
\hline & Post-docetaxel & & $0-2$ & Yes & $\begin{array}{l}\text { Risk factors for } \\
\text { seizure }\end{array}$ & \\
\hline \multirow[t]{2}{*}{$\begin{array}{l}\text { Prince } \\
\text { Edward } \\
\text { Island }\end{array}$} & Pre-docetaxel & $\begin{array}{l}\text { Asymptomatic } \\
\text { or mildly } \\
\text { symptomatic }\end{array}$ & $0-1$ & & & \\
\hline & Post-docetaxel & & $0-2$ & Yes & $\begin{array}{l}\text { Risk factors for } \\
\text { seizure }\end{array}$ & \\
\hline \multirow[t]{2}{*}{$\begin{array}{l}\text { Newfoundl } \\
\text { and and } \\
\text { Labrador }\end{array}$} & Pre-docetaxel & $\begin{array}{l}\text { Asymptomatic } \\
\text { or mildly } \\
\text { symptomatic }\end{array}$ & $0-1$ & & $\begin{array}{c}\text { Risk factors for } \\
\text { seizure }\end{array}$ & \\
\hline & Post-docetaxel & & $0-2$ & & $\begin{array}{l}\text { Risk factors for } \\
\text { seizure }\end{array}$ & $\begin{array}{c}\text { Approval period : } 4 \\
\text { months } \\
\text { Renewal will only be } \\
\text { approved if there is no } \\
\text { evidence of progression of } \\
\text { disease and the } \\
\text { development of } \\
\text { unacceptable toxicities }\end{array}$ \\
\hline
\end{tabular}

ECOG: Eastern Cooperative Oncology Group. 


\begin{tabular}{|c|c|c|c|c|c|c|}
\hline Province & $\begin{array}{c}\text { Abiraterone } \\
\text { acetate }+ \\
\text { prednisone }\end{array}$ & Symptomatic & $\begin{array}{l}\text { ECOG } \\
\text { status }\end{array}$ & $\begin{array}{c}\text { Is } \\
\text { "sandwich" } \\
\text { therapy } \\
\text { allowed? }\end{array}$ & Exclusion criteria & Other \\
\hline \multirow[t]{2}{*}{ Ontario } & Pre-docetaxel & $\begin{array}{l}\text { Asymptomatic } \\
\text { or mildly } \\
\text { symptomatic }\end{array}$ & $0-1$ & & $\begin{array}{c}\text { Viral hepatitis, } \\
\text { chronic liver } \\
\text { disease, clinically } \\
\text { significant heart } \\
\text { disease } \\
\text { Disease progression } \\
\text { while on abiraterone } \\
\text { acetate plus } \\
\text { prednisone }\end{array}$ & \\
\hline & $\begin{array}{c}\text { Post- } \\
\text { docetaxel }\end{array}$ & & $0-2$ & Vo & $\begin{array}{l}\text { Same as pre- } \\
\text { docetaxel }\end{array}$ & $\begin{array}{l}\text { Requests for } \\
\text { patients who } \\
\text { initiated } \\
\text { cabazitaxel or } \\
\text { enzalutamide } \\
\text { therapy within the } \\
3 \text { months preceding } \\
\text { the EAP request for } \\
\text { abiraterone acetate } \\
\text { plus prednisone } \\
\text { and who have not } \\
\text { had disease } \\
\text { progression will be } \\
\text { considered on a } \\
\text { case by case basis }\end{array}$ \\
\hline \multirow[t]{2}{*}{ Quebec } & Pre-docetaxel & $\begin{array}{l}\text { Asymptomatic } \\
\text { or mildly } \\
\text { symptomatic }\end{array}$ & $0-1$ & & $\begin{array}{l}\text { Prior enzalutamide } \\
\text { or abiraterone } \\
\text { acetate plus } \\
\text { prednisone } \\
\text { treatment }\end{array}$ & \\
\hline & $\begin{array}{c}\text { Post- } \\
\text { docetaxel }\end{array}$ & & $0-2$ & No & $\begin{array}{l}\text { Prior enzalutamide } \\
\text { or abiraterone } \\
\text { acetate plus } \\
\text { prednisone } \\
\text { treatment }\end{array}$ & \\
\hline \multirow[t]{2}{*}{ Alberta } & Pre-docetaxel & Symptomatic & & & & $\begin{array}{c}\text { mCRPC agents are } \\
\text { prescribed by } \\
\text { approved } \\
\text { designated } \\
\text { prescribers only }\end{array}$ \\
\hline & $\begin{array}{c}\text { Post- } \\
\text { docetaxel }\end{array}$ & & & Yes & Prior enzalutamide & \\
\hline \multirow[t]{2}{*}{$\begin{array}{l}\text { British } \\
\text { Columbia }\end{array}$} & Pre-docetaxel & & $0-1$ & & Prior enzalutamide & $\begin{array}{c}\text { Adequate renal and } \\
\text { liver function and } \\
\text { serum potassium } \\
\text { levels }\end{array}$ \\
\hline & $\begin{array}{c}\text { Post- } \\
\text { docetaxel }\end{array}$ & $\begin{array}{l}\text { Symptomatic } \\
\text { and ineligible }\end{array}$ & $0-2$ & No & Prior enzalutamide & $\begin{array}{l}\text { It will be funded if } \\
\text { the patient is }\end{array}$ \\
\hline
\end{tabular}




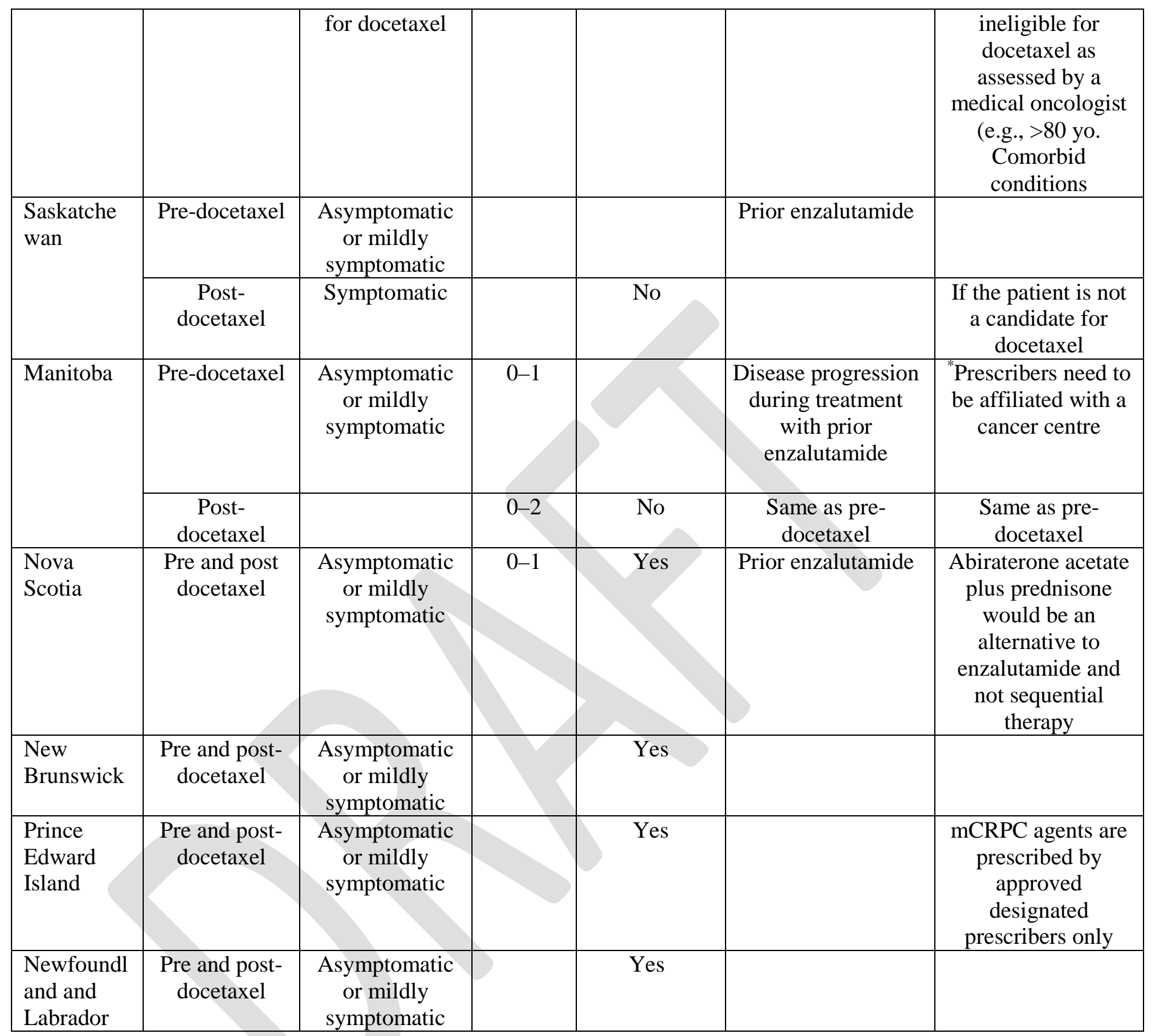

ECOG: Eastern Cooperative Oncology Group. 
Table 3. Public funding approval for radium-223, docetaxel, and cabazitaxel in each province

\begin{tabular}{|l|c|c|c|}
\hline \multicolumn{1}{|c|}{ Province } & Radium-223 & Docetaxel & Cabazitaxel \\
\hline Ontario & Yes & Yes & Yes \\
\hline Quebec & Yes & Yes & No \\
\hline Alberta & No & Yes & Yes \\
\hline British Columbia & Yes & Yes & Yes \\
\hline Saskatchewan & Yes & Yes & Yes \\
\hline Manitoba & Yes & Yes & Yes \\
\hline Nova Scotia & No & Yes & Yes \\
\hline New Brunswick & No & Yes & Yes \\
\hline $\begin{array}{l}\text { Prince Edward } \\
\text { Island, }\end{array}$ & No & Yes & No \\
\hline $\begin{array}{l}\text { Newfoundland and } \\
\text { Labrador }\end{array}$ & No & Yes & Yes \\
\hline
\end{tabular}




\begin{tabular}{|c|c|c|c|c|}
\hline Province & $\begin{array}{c}\text { Soft tissue metastasis } \\
\text { criteria }\end{array}$ & ECOG & $\begin{array}{c}\text { Combination with other } \\
\text { CRPC treatments }\end{array}$ & Other requirements \\
\hline Ontario & $\begin{array}{l}\text { No known visceral } \\
\text { metastatic disease }\end{array}$ & & $\begin{array}{l}\text { Cannot be combined with } \\
\text { cabazitaxel or enzalutamide } \\
\text { or abiraterone acetate plus } \\
\text { prednisone for mCRPC } \\
\text { If radium-223 is funded in } \\
\text { the pre-docetaxel setting, no } \\
\text { subsequent funding will be } \\
\text { considered in the post- } \\
\text { docetaxel setting }\end{array}$ & $\begin{array}{c}\text { A consultation with a } \\
\text { medical or radiation } \\
\text { oncologist has been done } \\
\text { before starting radium- } \\
223\end{array}$ \\
\hline Quebec & $\begin{array}{l}\text { No known visceral } \\
\text { metastatic disease }\end{array}$ & $0-2$ & $\begin{array}{l}\text { Will only be funded if the } \\
\text { disease has progressed } \\
\text { during or following } \\
\text { docetaxel unless there is } \\
\text { severe contraindication or } \\
\text { serious intolerance }\end{array}$ & \\
\hline $\begin{array}{l}\text { British } \\
\text { Columbia }\end{array}$ & $\begin{array}{l}\text { Patients have no known } \\
\text { liver, lung or brain } \\
\text { metastases and no } \\
\text { known symptomatic soft } \\
\text { tissue metastases (lymph } \\
\text { nodes, local disease, } \\
\text { etc.) }\end{array}$ & $0-2$ & $\begin{array}{l}\text { Will only be funded if } \\
\text { patients already received, are } \\
\text { not eligible for, decline, or } \\
\text { have no access to, other life- } \\
\text { prolonging treatment options } \\
\text { (e.g., docetaxel, abiraterone } \\
\text { acetate plus prednisone, } \\
\text { enzalutamide }\end{array}$ & $\begin{array}{l}\text { Recently seen by a } \\
\text { medical oncologist }\end{array}$ \\
\hline $\begin{array}{l}\text { Saskatche } \\
\text { wan }\end{array}$ & $\begin{array}{c}\text { No known visceral } \\
\text { metastatic disease } \\
\text { Lymphadenopathy <3 } \\
\text { cm } \\
\text { No untreated spinal cord } \\
\text { compression or fracture } \\
\text { requiring orthopedic } \\
\text { stabilization }\end{array}$ & $0-2$ & & 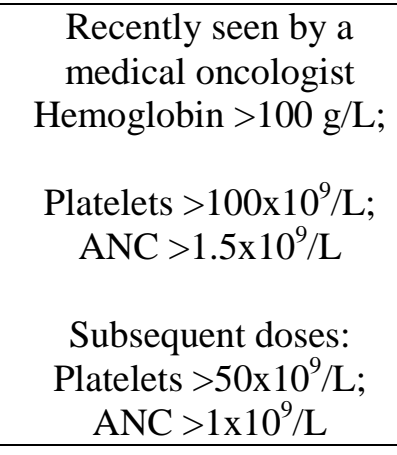 \\
\hline Manitoba & & & & \\
\hline
\end{tabular}

ECOG: Eastern Cooperative Oncology Group. 